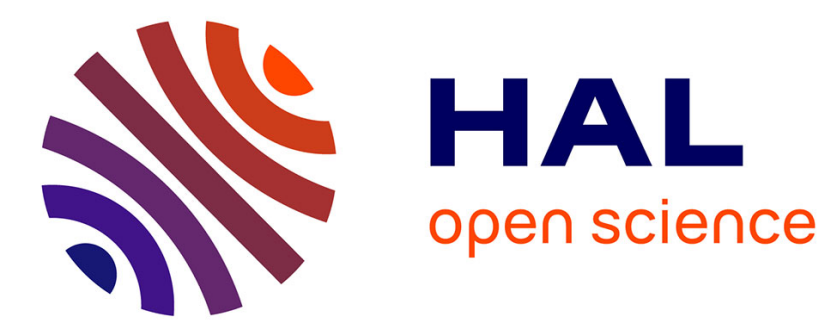

\title{
The role of savannas in the terrestrial Si cycle: A case-study from Lamto, Ivory Coast
}

\author{
Anne Alexandre, Mickael Bouvet, Luc Abbadie
}

\section{To cite this version:}

Anne Alexandre, Mickael Bouvet, Luc Abbadie. The role of savannas in the terrestrial Si cycle: A case-study from Lamto, Ivory Coast. Global and Planetary Change, 2011, 78 (3-4), pp.162 - 169. 10.1016/j.gloplacha.2011.06.007 . hal-01909564

\section{HAL Id: hal-01909564 https://hal.science/hal-01909564}

Submitted on 14 Dec 2018

HAL is a multi-disciplinary open access archive for the deposit and dissemination of scientific research documents, whether they are published or not. The documents may come from teaching and research institutions in France or abroad, or from public or private research centers.
L'archive ouverte pluridisciplinaire HAL, est destinée au dépôt et à la diffusion de documents scientifiques de niveau recherche, publiés ou non, émanant des établissements d'enseignement et de recherche français ou étrangers, des laboratoires publics ou privés. 


\title{
The role of savannas in the terrestrial Si cycle: A case-study from Lamto, Ivory Coast
}

\author{
Anne Alexandre ${ }^{\mathrm{a}, *}$, Mickael Bouvet ${ }^{\mathrm{a}}$, Luc Abbadie ${ }^{\mathrm{b}}$ \\ a CEREGE, CNRS, Aix-Marseille Université, Europôle de l'Arbois, BP 80, 13545, Aix en Provence, Cedex 04, France \\ b BioEMCo, CNRS, UPMC, ENS, 46 rue d'Ulm, 75230 Paris Cedex 05, France
}

\section{A R T I C L E I N F O}

\section{Article history:}

Received 2 February 2011

Accepted 15 June 2011

Available online 25 June 2011

\section{Keywords:}

silicon cycle

savanna

phytolith

chemical weathering

\begin{abstract}
A B S T R A C T
Savannas currently occupy a fifth of the earth's land surface and are predicted to expand in the next few centuries at the expense of tropical forests, mainly as a result of deforestation and human fires. Can such a vegetation trend impact, through changes in plant Si cycling, the lithogenic silicon (LSi) release into soils (through chemical weathering) and the net dissolved Si (DSi) outputs from soils to stream water (through chemical denudation)? The first step of an investigation requires quantifying the net Si fluxes involved in the plant/soil system. Here, a schematic steady-state Si cycle, established for a tropical humid savanna (Lamto, Ivory Coast) that developed on a ferruginous soil and is subjected to annual fires, is presented. Erosion was assumed to be insignificant. LSi and biogenic Si (BSi under the form of phytoliths) pools were measured, and Si fluxes were estimated from Si concentrations and mass balance calculation. Identification of plant and soil phytoliths indicated that the soil BSi pool is in equilibrium with the current BSi input by the savanna. In the soil column, mixing between a young rapidly recycled BSi pool and an old stable BSi pool is attested by a mixing line equation. Storage of the old BSi pool is assimilated as a BSi output from the plant/soil system. A BSi output additionally occurs after annual fires, when ashes are exported. Both BSi outputs decrease as much the BSi dissolution. In order to uptake constant DSi flux, the savanna increases by three to eight times the net LSi release, depending upon the post-fire ash exportation scenario. A comparison between savanna and rainforest Si cycles that maximizes the differences in plant/soil systems and minimizes differences in climate is presented. The comparison revealed that BSi storage is higher in the savanna soil than in the rainforest soil, mainly due to BSi production that is twice higher in the savanna (127 vs $67 \mathrm{~kg} / \mathrm{ha} / \mathrm{yr}$ ). The resulting LSi release that is enhanced by plant uptake is more than 1.5 higher in the savanna than in the rainforest (from 33 to $85 \mathrm{~kg} / \mathrm{ha} / \mathrm{yr}$ in the savanna vs $21 \mathrm{~kg} / \mathrm{ha} / \mathrm{yr}$ in the rainforest). On the contrary, DSi output from soils to stream water, which is not controlled by plant Si cycling but more likely by the soil hydrological regime (or meteoric weathering), is close to twice as high in the rainforest/ferrallitic soil ecosystem (16 vs $9 \mathrm{~kg} / \mathrm{ha} / \mathrm{yr}$ ). This case study suggests that the predicted expansion of savannas at the expense of forests should significantly increase DSi uptake by plants, BSi storage in soils, BSi output with ash exportation, and, hence, LSi release through chemical weathering, without direct impact on DSi outputs from soils to stream water. Tracks for further assessing the role of plant Si cycling on chemical weathering, Si and C cycles were suggested: 1) estimates of BSi fluxes that were wrongly based on the assumption that the amount of DSi leached out from soils is linked to the magnitude of plant Si cycling and/or to BSi concentration in soils should be reappraised and 2) changes in the magnitude of plant Si cycling should be accounted in geochemical carbon cycle models, for one of the plant-induced weathering mechanisms.
\end{abstract}

(c) 2011 Elsevier B.V. All rights reserved.

\section{Introduction}

It is well known that higher plants and associated mycorrhizal fungi enhance silicate weathering in the rhizosphere by silicate dissolution, chelation, and the root absorption of nutrients and other elements such as silicon (Si) (Kelly et al., 1998; Moulton et al., 2000; Hinsinger et al., 2001; Pagani et al., 2009; Taylor et al., 2009). Si is taken up by the roots in its dissolved form (DSi), translocated in the

\footnotetext{
* Corresponding author. Tel.: + 334429715 54; fax: + 33442971540 . E-mail address: alexandre@cerege.fr (A. Alexandre).
}

sap, and deposited in the cells as biogenic silicon (BSi) or micrometric hydrous amorphous silica particles, also called phytoliths. When plants decay, phytoliths are either dissolved in the litter or the soils, or incorporated into the soil column or exported by physical erosion to the regional watershed. The concentration of phytolith-BSi in ecosystems is low and ranges from less than $0.01 \%$ of dry weight in angiosperms to more than $8 \%$ of dry weight in grasses, from 0.05 to $8 \%$ of dry weight in soil humic horizons, from 0.5 to $2 \%$ of dry weight in the riverine suspended load, and from 0 to several \% of dry weight in lake and sea sediments (e.g. Geis, 1973; Bozarth, 1992; Runge, 1996, 1999; Alexandre et al., 1997, 1999; Meunier et al., 1999; Webb and Longstaffe, 2000, 2002; Conley, 2002; Cary et al., 2005; Derry et al., 
2005; Blecker et al., 2006; Piperno, 2006; Hughes et al., 2011). On the other hand, given the abundance of continental plant biomass, DSi fluxes from soils to plants and particulate BSi fluxes from plants to soils are high. At the global scale, higher plant BSi production is estimated to be comparable in magnitude to oceanic BSi production (respectively, 60-200 Tmol Si/yr and $240 \mathrm{Tmol} \mathrm{Si} / \mathrm{yr}$, Conley, 2002). At regional and local scales, DSi plant uptake and particulate BSi release can, individually, exceed by more than two times the DSi fluxes exported from soils to watersheds (Bartoli, 1983; Lucas et al., 1993; Alexandre et al., 1997; Meunier et al., 1999; Blecker et al., 2006). As a result, a major proportion of the DSi in stream solutions passes through the BSi pool, as recently demonstrated from geochemical studies measuring the $\delta^{30} \mathrm{Si}$ or Ge/Si compositions in terrestrial waters (Ding et al., 2004; Derry et al., 2005; Ziegler et al., 2005; Struyf et al., 2006; Opfergelt et al., 2010).

Savannas currently occupy a fifth of the earth's land surface as a result of both climate and fires (endemic wild fires as well as human fires) (Mistry, 2000; Bond et al., 2005; Sankaran et al., 2005). Savannas are today predicted to expand at the expense of tropical forests, mainly as a result of deforestation and human fires (Favier et al., 2004; IPCC, 2007; Delire et al., 2008; Sala et al., 2000). Can such a vegetation trend impact, through plant Si cycling, lithogenic silicon release (LSi) into soils (through chemical weathering) and/or net DSi outputs from soils to stream water (through chemical denudation)? Is it significant regarding other identified driving variables such as meteoric weathering, adsorption/desorption on soil mineral surfaces, and the formation of soil secondary minerals? Answering such questions will contribute to refining the role of vegetation changes on global silicate weathering rates and atmospheric $\mathrm{CO}_{2}$ consumption (Berner, 1997; Moulton and Berner, 1998; Gaillardet et al., 1999a, 1999b; Moulton et al., 2000; Dessert et al., 2003; Dupré et al., 2003; Street-Perrott and Barker, 2008), and on terrestrial Si fluxes that reach the oceans, feed the marine phytoplankton and participate to the so called $\mathrm{CO}_{2}$ biological pump (Harrison, 2000; Tréguer and Pondaven, 2000); two main processes that may retroactively contribute to climate change.

Although recent reviews highlighted the need for estimating pools and fluxes of the terrestrial Si cycle (Conley, 2002; Sommer et al., 2006; Conley et al., 2008; Street-Perrott and Barker, 2008; Laruelle et al., 2009; Cornelis et al., 2011), their impacts were limited by the striking lack of quantitative data. The first step of an investigation requires quantifying the net $\mathrm{Si}$ fluxes at the interface between soils and plants. Such quantification is arduous when one uses tracers such as $\delta^{30} \mathrm{Si}$ and $\mathrm{Ge} / \mathrm{Si}$ values of soil water. Indeed, the sum of soil processes leads to cumulated $\mathrm{Si}$ isotopic fractionations of close amplitude that prevent one from distinguishing BSi from LSi inputs in soil water. As for Ge/Si values, since Ge is stock-piled in the roots, the $\mathrm{Ge} / \mathrm{Si}$ composition of soil water is lowered by BSi dissolution but is not impacted by plant DSi uptake (Opfergelt et al., 2010). An alternative method is, for a given plant/soil system that is not subjected to erosion, to estimate from measured Si concentrations a schematic steady-state Si cycle and infer plant DSi uptake and BSi dissolution fluxes. Such Si cycles have previously been estimated for rainforest and temperate grasslands ecosystems (Alexandre et al., 1997; Blecker et al., 2006). Although such studies have led to rough estimations, they have also revealed that no matter the plant/soil system, BSi dissolution alone is not sufficient to meet the annual requirements for plant Si uptake. Indeed, the particulate BSi produced by plants is stored in soils long enough to be assimilated as a BSi output from the system. Consequently plant $\mathrm{Si}$ cycling significantly enhances LSi dissolution or silicate chemical weathering.

In the present study, we quantified a steady-state schematic Sicycle for a tropical humid savanna that developed on a ferruginous soil and that was subjected to annual fires. Si fluxes were compared to those previously obtained for a rainforest ecosystem that developed, under similar climate conditions, on a ferrallitic soil (Alexandre et al.,
1997). The comparison brought several lines of evidence to the forefront for assessing the significance of forest/savanna changes on terrestrial Si cycling, LSi release through chemical weathering and DSi output through chemical denudation.

\section{Materials and methods}

The humid grass savanna studied for this work is located in the Lamto scientific station (Ivory Coast, $6^{\circ} 13 \mathrm{~N}, 5^{\circ} 02 \mathrm{~W}, 75$ to $125 \mathrm{~m}$ above sea level in elevation), at the southern and wettest edge of the Guinean savanna domain ("V" Baoulé), at the entrance to the rainforest domain (White, 1983). The station was established in the 1960s. Forty years of ecological studies for the Lamto savanna ecosystem were recently synthesized in Abbadie et al. (2006). The climate of the region is tropical humid with a two to three month dry season, and is controlled by the position of the Intertropical Convergence Zone (ICZ) and the South West Monsoon. Mean annual precipitation (MAP) is approximately $1200 \mathrm{~mm}$ and the mean annual temperature (MAT) is fairly constant at approximately $27.8^{\circ} \mathrm{C}$. The grass savanna is located on the lower part of a gentle slope (1\%) and is made of a continuous grass layer dominated by the perennial tall C4-grass species Loudetia simplex (Pannicoideae grass subfamily). Trees and shrubs are rare with the exception of the palm Borassus aethiopum. Higher on the slope, tree/ shrub Andropogoneae savanna and savanna woodland occur. Annual fires burn approximately $80 \%$ of the standing grass biomass at Lamto preventing tree invasion (Abbadie et al., 2006). In the northern section of the station, the forest regularly advances over grass savanna in plots protected against fire.

The soil (SB1) is ferruginous, with a vertic horizon at depth. The top portion of the soil is made of a humic horizon (the A1 horizon) from 0 to $30 \mathrm{~cm}$ in depth, and a sandy horizon (the A2 horizon) from 30 to $85 \mathrm{~cm}$ in depth. The lower portion is made of a sandy-clayed vertic horizon ( $85-185 \mathrm{~cm}$ ) above a saprolite and a granitic bedrock. Earthworms and termites are present in the soil column.

Both the top portion of the soil $(0-85 \mathrm{~cm})$ and grasses were sampled in 1981. Aboveground grasses were collected over a surface area of $10 \mathrm{~m}^{2}$. Stems and leaves of Loudetia simplex were sorted, ground, and dried. The rhizosphere was cored from 0 to $50 \mathrm{~cm}$ in depth (Abbadie, 1984). Grass roots with a diameter between 1 and $10 \mathrm{~mm}$ were also sorted, ground, and dried. As roots are difficult to fully remove from the soil remnants, a small amount of the aboveground components incorporated into the litter and the humus may have remained.

Phytoliths were extracted from soil samples after the dissolution of amorphous iron ( $\mathrm{Fe}$ ) and aluminum ( $\mathrm{Al}$ ) oxides, the chemical oxidation of organic matter, Fe reduction and dissolution, clay fraction removal, and densimetric separation following Kelly (1990) and Alexandre et al. (1997). Surface cleaning and the chemical oxidation of soil organic matter (SOM) of above- and belowground biomass samples were done following Webb and Longstaffe (2000). The dry weight of phytoliths $>2 \mu \mathrm{m}$ in diameter was measured and related to the initial dry weight of the soil or the plant material. The purity of the phytolith assemblages was checked under a microscope and a weight correction was made for the presence of quartz particles in the soil and root assemblages (using the proportion and the density of quartz grain contamination). The phytolith content of the soil samples is a minimal estimate since phytoliths with diameters lower than $2 \mu \mathrm{m}$ were not taken into account. More than 200 phytoliths with determined morphology were counted and classified according to Bremond et al. (2005b), and named after the International Code for Phytolith Nomenclature 1.0 (Madella et al., 2005).

Some of the physical and chemical characteristics of the soil were presented in Abbadie et al. (2006). Additional soil elemental ( $\mathrm{Si}, \mathrm{Al}$, and $\mathrm{Fe}$ ) and mineralogical compositions (quartz, kaolinite, and hematite) were determined by I.C.P.-A.E.S. after alkaline fusion and from X-ray diffraction spectra obtained on random oriented powders 
with a Phillips PW 3710 X-ray diffractometer (Co K $\alpha$ radiation). Soil organic carbon (SOC) was measured with a $\mathrm{C}-\mathrm{H}-\mathrm{N}$ analyzer.

\section{Results}

Phytolith assemblages from the leaves, the root concentrate of L. simplex and from the SB1 ferruginous soil top portion are presented in Table 1 . The leaves of $L$. simplex yielded a typical Panicoideae grass assemblage dominated by the Bilobate short cell type (Alexandre et al., 1998; Bremond et al., 2005b). In the root concentrate assemblage, the Bilobate short cell type was still present, although in a much lower proportion, supporting above-ground contamination. Two additional species types were abundant, as follows: (1) Papillae cell type produced by Cyperaceae species, and (2) Globular psilate type with no demonstrated taxonomic significance. The phytolith assemblages along the soil column showed a consistent pattern. Two phytolith indices, previously calibrated as proxies of tropical grassland physiognomic characters (Alexandre et al., 1998; Bremond et al., 2005a, 2005b), could be calculated. Iph is the percentage of Chloridoideae short cell types (Saddle) versus the sum of Poaceae short cell types. Iph remained null indicating the exclusive contribution of phytoliths from the Panicoideae C4-tall grass subfamily, in agreement with the dominance of $L$. simplex in the savanna. $\mathrm{D} / \mathrm{P}$ is the ratio of the phytolith type diagnostic of tropical ligneous dicotyledons (Globular granulate) versus diagnostic Poaceae phytoliths (i.e. the sum of short cell types plus Parallelepipedal and Cuneiform bulliform cell types). D/P remained lower than 0.4 from 0 to $50 \mathrm{~cm}$ in depth and increased to 0.9 at greater depths. A D/P value lower than one indicates a limited contribution from tropical shrubs and trees (Bremond et al., 2005a) rare in the current grass savanna. A slight increase of $\mathrm{D} / \mathrm{P}$ at depth can be explained by the increasing contribution of older phytoliths from shrubs or trees, either due to higher tree cover density in the past or to a higher resistance of tree and shrub phytoliths to dissolution. Interestingly, SOM $\delta{ }^{13} \mathrm{C}$ values previously obtained from another ferruginous soil column at Lamto (Martin et al., 1990) showed a slight decrease of $-3 \%$ with depth that was also attributed to a higher proportion of old recalcitrant SOM at depth, formerly produced by shrubs and trees.

The phytolith-BSi content measured in the aboveground parts of L. simplex was $0.8 \%$ of dry weight (Table $2 a$ ), in agreement with the range of BSi content in grasses reported in the literature (e.g. Webb and Longstaffe, 2000; Blecker et al., 2006). In the belowground parts, the phytolith-BSi content was $0.1 \%$ of the dry weight (Table $2 \mathrm{a}$ ).
Table 2a

Plant biogenic Si pools (BSi) and production.

\begin{tabular}{lllllc}
\hline & $\begin{array}{l}\text { Mean } \\
\text { biomass } \\
(\mathrm{t} / \mathrm{ha})\end{array}$ & $\begin{array}{l}\text { BSi } \\
\text { content } \\
(\%)\end{array}$ & $\begin{array}{l}\text { BSi } \\
\text { pool } \\
(\mathrm{kg} / \mathrm{ha})\end{array}$ & $\begin{array}{l}\text { Mean } \\
\text { production } \\
(\mathrm{t} / \mathrm{ha} / \mathrm{yr})\end{array}$ & $\begin{array}{l}\text { BSi } \\
\text { production } \\
(\mathrm{kg} / \mathrm{ha} / \mathrm{yr})\end{array}$ \\
\hline LS $^{\mathrm{b}}$ aboveground parts & 4 & 0.8 & 33 & 11 & 90 \\
LS $^{\mathrm{b}}$ belowground parts & 19 & 0.1 & 21 & 34 & 37 \\
Sum & & & $\mathbf{5 4}$ & & $\mathbf{1 2 7}$ \\
\hline
\end{tabular}

${ }^{\text {a }}$ From Menaut and Cesar (1979) and Abbadie et al. (2006).

b Loudetia simplex.

However, due to the potential for aboveground phytolith contamination in the root concentrate this value may be overestimated.

The mineralogical composition of the upper soil section (Table 3) was fairly constant and typical of well drained ferruginous soils dominated by quartz (from 88.9 to $95.5 \%$ of dry weight), with minor contributions of kaolinite (from 3.9 to $5.6 \%$ of dry weight) and hematite (from 0.2 to $0.3 \%$ of dry weight). The clay size fraction $(<2 \mu \mathrm{m})$ remained lower than $10 \%$ of dry weight. The SOC content in SB1 (Table 3) was weak, ranging from 0.2 to $0.4 \%$ of dry weight and showed a logarithmic decrease with depth typical of soils with homogeneous SOM translocation, fast SOM mineralization on top and slow mineralization at depth. Indeed, a rapid 3.9 to $2.4 \% / \mathrm{yr}$ decrease in SOM mineralization was previously calculated for the upper $25 \mathrm{~cm}$ of a similar soil at Lamto (Martin et al., 1990; Abbadie et al., 2006). The phytolith content (Table $2 \mathrm{~b}$ ) showed a rapid decrease from 0.22 to $0.03 \%$ of dry weight in the top portion of the soil.

\section{Discussion}

\subsection{Estimation of Si pools}

The steady-state plant/soil Si cycle to be schematized includes four Si pools (Alexandre et al., 1997), as follows: (1) live plant biomass (biomass BSi or phytoliths in plant), (2) soil biogenic components (soil BSi or soil phytoliths), (3) soil lithogenic components including primary and secondary minerals (soil LSi), and (4) soil dissolved exchangeable Si (soil DSi).

The above- and belowground biomass of L. simplex in Lamto savannas accounts for 4 and 19 t/ha, respectively (Menaut and Cesar, 1979). Taking into account the measured phytolith-BSi contents, the biomass BSi pool accounts for $33 \mathrm{~kg} / \mathrm{ha}$ (in the aboveground part of

Table 1

Phytolith assemblages from the SL Loudetia simplex savanna/SB1 ferruginous soil ecosystem.

\begin{tabular}{|c|c|c|c|c|c|c|c|c|c|c|c|c|}
\hline \multirow[t]{3}{*}{ Sample } & \multicolumn{4}{|c|}{ Grasses ph.t. ${ }^{a}$} & \multirow{2}{*}{$\begin{array}{l}\text { Unknown ph.t. } \\
\text { Globular } \\
\text { psilate }\end{array}$} & \multirow{2}{*}{$\begin{array}{l}\text { Sedges ph.t. } \\
\text { Papillae }\end{array}$} & \multicolumn{2}{|c|}{ Tropical trees ph.t. $^{a}$} & \multirow{2}{*}{$\begin{array}{l}\text { Palms ph.t. } \\
\text { Globular } \\
\text { crenate }\end{array}$} & \multirow[b]{2}{*}{$\begin{array}{l}\text { Unclassified } \\
\text { ph.t. }^{\text {a }}\end{array}$} & \multicolumn{2}{|c|}{$\begin{array}{l}\text { Phytolith } \\
\text { indexes }\end{array}$} \\
\hline & $\begin{array}{l}\text { Bilobate } \\
\text { short cell }\end{array}$ & Elongate & $\begin{array}{l}\text { Parallelepiped and Cuneiform } \\
\text { bulliform cell }\end{array}$ & $\begin{array}{l}\text { Acicular } \\
\text { hair cell }\end{array}$ & & & $\begin{array}{l}\text { Globular } \\
\text { granulate }\end{array}$ & $\begin{array}{l}\text { Vascular } \\
\text { cell }\end{array}$ & & & $\mathrm{D} / \mathrm{P}^{\mathrm{b}}$ & $\begin{array}{l}\mathrm{Iph}^{\mathrm{c}} \\
(\%)\end{array}$ \\
\hline & \multicolumn{12}{|c|}{$\%$ of counted phytoliths } \\
\hline \multicolumn{13}{|c|}{ Loudetia simplex } \\
\hline Leaves & 76 & 11 & 1 & 1 & 0 & 0 & 0 & 0 & 0 & 11 & & \\
\hline $\begin{array}{l}\text { Root } \\
\text { concent }\end{array}$ & 17 & 3 & 3 & 0 & 17 & 34 & 0 & 0 & 0 & 26 & & \\
\hline \multicolumn{13}{|c|}{ Soil (SB1) depth (cm) } \\
\hline $0 / 5$ & 13.6 & 16.9 & 18.2 & & 8.4 & 0 & 5.3 & 5.3 & 2.7 & 29.6 & 0.2 & 0 \\
\hline $5 / 10$ & 13.8 & 18.7 & 22.7 & & 6.9 & 0 & 4.6 & 5.9 & 3.6 & 23.8 & 0.1 & 0 \\
\hline $10 / 20$ & 5.2 & 12.4 & 21.6 & & 11.1 & 0 & 10.5 & 7.2 & 2.6 & 29.4 & 0.4 & 0 \\
\hline $20 / 30$ & 4.4 & 13.7 & 24.9 & & 13.7 & 0 & 11.9 & 4.1 & 3.0 & 24.3 & 0.4 & 0 \\
\hline $30 / 50$ & 1.8 & 8.3 & 28.8 & & 8.9 & 0 & 11.2 & 3.2 & 1.8 & 36.0 & 0.4 & 0 \\
\hline $50 / 70$ & 0.9 & 4.0 & 28.9 & & 15.7 & 0 & 26.6 & 0.7 & 4.0 & 19.2 & 0.9 & 0 \\
\hline $70 / 85$ & 1.0 & 4.7 & 29.8 & & 8.8 & 0 & 26.8 & 0.4 & 2.5 & 26.0 & 0.9 & 0 \\
\hline
\end{tabular}

a Phytolith types (ph.t.) named after the International Code for Phytolith Nomenclature 1.0 (Madella et al., 2005).

b Ratio of ph.t. diagnostic of tropical ligneous dicotyledons (Globular granulate) versus ph.t. diagnostic of grasses (here sum of Bilobate, Parallelepipedal and Cuneiform bulliform cell, Acicular hair cell) according to Bremond et al. (2005a).

c Percentage of Chloridoideae short cell type (Saddle) versus the sum of Poaceae short cell types (here Saddle, Bilobate, Cross) according to Bremond et al. (2005b). 
Table 2b

Lithogenic and biogenic Si pools (LSi and BSi) in the ferruginous soil; extrapolated concentrations (cf Section 4.1) are displayed in italic.

\begin{tabular}{|c|c|c|c|c|c|c|c|c|}
\hline \multirow{2}{*}{$\begin{array}{l}\text { Soil (SB1) depth } \\
\mathrm{cm}\end{array}$} & \multirow{2}{*}{$\begin{array}{l}\text { Total } \mathrm{SiO}_{2} \\
\text { (\% dry wt.) }\end{array}$} & \multirow{2}{*}{$\begin{array}{l}\text { Total } \mathrm{Si}^{\mathrm{a}} \\
(\mathrm{t} / \mathrm{ha} / 10 \mathrm{~cm})\end{array}$} & \multirow{2}{*}{$\begin{array}{l}\text { Phytolith } \\
\text { (\% dry wt.) }\end{array}$} & \multicolumn{2}{|l|}{$\mathrm{BSi}$} & \multirow{2}{*}{$\begin{array}{l}\text { LSi } \\
(\mathrm{t} / \mathrm{ha} / 10 \mathrm{~cm})\end{array}$} & \multirow{2}{*}{$\begin{array}{l}\text { Stable BSi } \\
(\mathrm{t} / \mathrm{ha} / 10 \mathrm{~cm})\end{array}$} & \multirow[t]{2}{*}{ Decreasing BSi } \\
\hline & & & & (\% dry wt.) & $(\mathrm{t} / \mathrm{ha} / 10 \mathrm{~cm})$ & & & \\
\hline $0-5$ & 94.6 & 751.9 & 0.53 & 0.22 & 3.3 & 748.6 & 0.6 & 2.7 \\
\hline $5-10$ & 97.7 & 776.4 & 0.50 & 0.21 & 3.2 & 773.2 & 0.6 & 2.5 \\
\hline 10-20 & 96.2 & 764.6 & 0.37 & 0.16 & 2.3 & 762.2 & 0.6 & 1.7 \\
\hline $20-30$ & 97.2 & 772.8 & 0.22 & 0.09 & 1.4 & 771.4 & 0.6 & 0.7 \\
\hline $30-50$ & 97.2 & 772.8 & 0.32 & 0.13 & 2.0 & 770.8 & 0.6 & 1.4 \\
\hline $50-70$ & 93.5 & 743.6 & 0.19 & 0.08 & 1.2 & 742.4 & 0.6 & 0.6 \\
\hline $70-85$ & 91.1 & 724.0 & 0.08 & 0.03 & 0.5 & 723.5 & 0.6 & -0.1 \\
\hline $85-105$ & & 724.0 & & & 0.8 & 723.2 & 0.6 & 0.2 \\
\hline $105-125$ & & 724.0 & & & 0.8 & 723.2 & 0.6 & 0.1 \\
\hline $125-145$ & & 724.0 & & & 0.7 & 723.3 & 0.6 & 0.1 \\
\hline $145-165$ & & 724.0 & & & 0.7 & 723.3 & 0.6 & 0.0 \\
\hline $165-185$ & & 724.0 & & & 0.6 & 723.4 & 0.6 & 0.0 \\
\hline Average in $t / h a / 10 \mathrm{~cm}$ & & 743.8 & & & 1.5 & 742.4 & 0.6 & 0.8 \\
\hline Sum in t/ha/ $185 \mathrm{~cm}$ & & 13,761 & & & 27 & 13,734 & 12 & 15 \\
\hline
\end{tabular}

a Calculated for a soil density of $1.5 \mathrm{t} / \mathrm{m}^{3}$ (Le Roux, 1995).

L. simplex) plus $21 \mathrm{~kg} / \mathrm{ha}$ (in the belowground part), for a total of $54 \mathrm{~kg} / \mathrm{ha}$ (Table 2a).

Measured soil BSi content was expressed in $\mathrm{t} / \mathrm{ha} / 10 \mathrm{~cm}$ using the measured soil phytolith-BSi concentration in\% dry weight, the average soil bulk density $\left(1.5 \mathrm{t} / \mathrm{m}^{3}\right.$; Le Roux, 1995) and the horizon thickness $(10 \mathrm{~cm})$ (Table 2b, Fig. 1(a)). Logarithm distributions of SOC and phytoliths are typical of soils in equilibrium with vegetation inputs and decomposition/dissolution outputs (Alexandre et al., 1997). In order to estimate BSi and SOC contents of the lower soil portion (85$185 \mathrm{~cm}$ ), both concentrations (C) were extrapolated using a Ln-Ln model (Jobbágy and Jackson, 2000) according to the equation Ln $\mathrm{C}=\mathrm{S}$ Ln $\mathrm{d}+\mathrm{I}$, where the slope of the model $(\mathrm{S})$ characterizes the relative rate of the decrease with depth (d) and the intercept (I) indicates the absolute content. Extrapolated SOC and BSi values, expressed in t/ha/10 cm, are displayed Table $2 \mathrm{~b}$ and Fig. 1(a).

The soil BSi distribution, in equilibrium with phytolith inputs from above vegetation, can be modeled assuming two pools of BSi with a different mean residence time (MRT) (Alexandre et al., 1997; Blecker et al., 2006). One pool rapidly dissolves and is maintained in dynamic equilibrium with litter inputs. This young pool decreases to traces at depth, as a logarithmic function. A second pool has a very low turnover. According to the model, this old inactive pool remains relatively constant along the soil column and reaches $100 \%$ of the phytolith content at the bottom of the soil. In the present case (Fig. 1 (b)), the young decreasing pool and the old stable pool account respectively for 15 and $12 \mathrm{t} /$ ha (Table $2 \mathrm{~b}$ ). Important to note is that the proportion of Globular granulate phytolith type increases with depth (Table 1) in parallel with the stable pool. The mixing between a young decreasing pool with few Globular granulates and an old stable pool with a larger amount of Globular granulate is attested by the mixing line equation, as follows: $\%$ Globular granulate $=\mathrm{f}(1 / \mathrm{BSi}$ content) with a linear $\mathrm{R}^{2}=0.9$ (Fig. $1(\mathrm{c})$ ).
The soil LSi pool (quartz and kaolinite) can be roughly approximated using total Si content, measured up to $85 \mathrm{~cm}$ in depth and extrapolated below, minus BSi content. Extrapolated LSi values are assumed similar to the LSi content at 70/85 cm depth. The soil LSi pool approximates 13,734 t/ha (Table $2 \mathrm{~b}$ ).

\subsection{Estimation of Si fluxes}

The Si input fluxes to soil are, as follows: (1) the phytolith annual input from plant to soil (BSi input), (2) phytolith dissolution (BSi dissolution), and (3) the lithogenic weathering release (LSi release) which is a net input equal to LSi dissolution minus the neoformation of silicates. The Si input from rainfall, which was estimated as $3.3 \mathrm{~kg} / \mathrm{ha} / \mathrm{yr}$ at Lamto (Villecourt and Roose, 1978), was ignored in the present study. The Si output fluxes from the soil are, as follows: (1) the phytolith storage in the soil profile (BSi storage), (2) the DSi plant uptake, and (3) the DSi output in groundwaters and stream waters (DSi output).

The BSi annual production can be estimated using the averaged annual aboveground and belowground biomass production (Abbadie et al., 2006) multiplied by their measured BSi content (Table 2a). The resulting annual BSi production reaches $127 \mathrm{~kg} / \mathrm{ha} / \mathrm{yr}$ (Table 2a), which is also equal to the annual DSi plant uptake by the L. simplex savanna. When annual fires occur, burning $80 \%$ of the above-ground biomass, the BSi contained in the ashes may be exported by wind at a regional scale or exported by runoff at the beginning of the rainy season (Villecourt and Roose, 1978). Therefore, part of the BSi production may be removed from the BSi annual input to soil. In the absence of quantifiable data for ash exportation, several scenarios were assumed (Table 2c), as follows: (1) ash-BSi output is not significant and the BSi input to soil equals the total BSi production or $127 \mathrm{~kg} / \mathrm{ha} / \mathrm{yr}$; (2) $50 \%$ of the ash-BSi is exported ( $36 \mathrm{~kg} / \mathrm{ha} / \mathrm{yr}$ ) and the BSi input to soil equals $91 \mathrm{~kg} / \mathrm{ha} / \mathrm{yr}$; and (3) $90 \%$ of the ash-BSi is

Table 2c

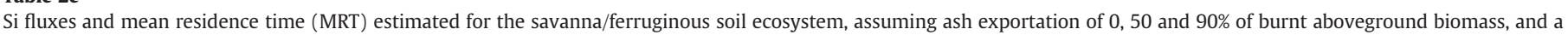
rainforest/ferrallitic soil ecosystem after Alexandre et al. (1997).

\begin{tabular}{|c|c|c|c|c|c|c|c|c|c|c|}
\hline \multirow[t]{2}{*}{ Ecosystem } & \multicolumn{2}{|c|}{$\begin{array}{l}\text { Ash } \\
\text { exportation }^{\mathrm{a}}\end{array}$} & \multirow[t]{2}{*}{$\begin{array}{l}\text { DSi plant } \\
\text { uptake }\end{array}$} & \multirow[t]{2}{*}{$\begin{array}{l}\text { BSi input } \\
\text { (incl. ash } \\
\text { input) }\end{array}$} & \multirow[t]{2}{*}{$\begin{array}{l}\text { BSi } \\
\text { storage }^{\mathrm{b}}\end{array}$} & \multirow[t]{2}{*}{$\begin{array}{l}\text { BSi } \\
\text { dissolution }\end{array}$} & \multirow[t]{2}{*}{$\begin{array}{l}\text { DSi } \\
\text { output }\end{array}$} & \multirow[t]{2}{*}{$\begin{array}{l}\mathrm{LSi} \\
\text { release }\end{array}$} & \multirow{2}{*}{$\begin{array}{l}\text { Stable } \\
\text { BSi MRT } \\
(\mathrm{yr})\end{array}$} & \multirow[t]{2}{*}{$\begin{array}{l}\text { Total BSi } \\
\text { MRT }\end{array}$} \\
\hline & $(\%)$ & $(\mathrm{kg}$ & & & & & & & & \\
\hline Savanna/ferruginous soil & 0 & 0 & 127 & 127 & 24 & 103 & 9 & 33 & 486 & 213 \\
\hline Savanna/ferruginous soil & 50 & 36 & 127 & 91 & 17 & 74 & 9 & 62 & 678 & 298 \\
\hline Savanna/ferruginous soil & 90 & 65 & 127 & 62 & 12 & 50 & 9 & 85 & 993 & 436 \\
\hline Rainforest/ferrallitic soil & 0 & 0 & 67 & 67 & 5 & 62 & 16 & 21 & 1400 & 397 \\
\hline
\end{tabular}

a With fire burning $80 \%$ of the aboveground parts (Nacro et al., 1996).

b With $19 \%$ of the BSi input feeding a stable BSi pool (Section 4.2, Fig. 1). 
Table 3

Elemental, mineralogical and soil organic carbon (SOC) composition of the upper SB1 ferruginous soil section.

\begin{tabular}{|c|c|c|c|c|c|c|c|c|}
\hline $\begin{array}{l}\text { Soil (SB1) depth } \\
(\mathrm{cm})\end{array}$ & $\mathrm{Al}_{2} \mathrm{O}_{3}$ (\% dry wt.) & $\mathrm{SiO}_{2}$ total & $\mathrm{Fe}_{2} \mathrm{O}_{3}$ total & $\begin{array}{l}\text { Kaolinite } \\
\text { (\% dry wt.) }\end{array}$ & Quartz & Hématite & $\begin{array}{l}<2 \mu \mathrm{m} \\
\text { (\% dry wt.) }\end{array}$ & $\begin{array}{l}\text { SOC } \\
\text { (\% dry wt.) }\end{array}$ \\
\hline $0-5$ & 1.9 & 94.6 & 0.2 & 4.8 & 92.4 & 0.2 & 5.7 & 0.34 \\
\hline $5-10$ & 1.8 & 97.7 & 0.2 & 4.6 & 95.5 & 0.2 & 4.7 & 0.42 \\
\hline $10-20$ & 1.7 & 96.2 & 0.2 & 4.4 & 94.1 & 0.2 & 4.6 & 0.41 \\
\hline $20-30$ & 1.5 & 97.2 & 0.2 & 3.9 & 95.4 & 0.2 & 4.1 & 0.28 \\
\hline $30-50$ & 1.9 & 97.2 & 0.2 & 4.8 & 95.0 & 0.2 & 9.9 & 0.22 \\
\hline $50-70$ & 2.2 & 93.5 & 0.3 & 5.6 & 90.9 & 0.3 & 6.1 & 0.19 \\
\hline $70-85$ & 1.9 & 91.1 & 0.2 & 4.8 & 88.9 & 0.2 & 5.3 & 0.20 \\
\hline
\end{tabular}

exported (65 kg/ha/yr) and the BSi input to soil equals $62 \mathrm{~kg} / \mathrm{ha} / \mathrm{yr}$. The stable BSi pool, that accounts for $100 \%$ of BSi at the bottom of the soil column $(0.6 \mathrm{t} / \mathrm{ha} / 10 \mathrm{~cm})$ and is assumed to be constant with depth, also represents $19 \%$ of BSi at 0 to $5 \mathrm{~cm}$. By assuming that BSi content in the top $0-5 \mathrm{~cm}$ depth represents the BSi input from vegetation, after fire occurrence and before translocation and dissolution (Alexandre et al., 1997), the BSi storage accounts for $19 \%$ of the vegetation BSi input (Fig. 1). Depending upon the ash exportation scenario, phytolith-BSi storage ranges from 24 to $12 \mathrm{~kg} / \mathrm{ha} / \mathrm{yr}$ (Table 2c). BSi dissolution equals BSi input minus BSi storage, or ranges between 103 and $50 \mathrm{~kg} / \mathrm{ha} / \mathrm{yr}$ (Table 2c).

Soil DSi output was measured at Lamto by Villecourt and Roose (1978) and accounts for $9 \mathrm{~kg} / \mathrm{ha} / \mathrm{yr}$. Sub-surface lateral flow was found to be negligible. Net LSi release is equal to the sum of the DSi output from soil water and the DSi plant uptake minus the BSi dissolution, or ranges from 33 to $85 \mathrm{~kg} / \mathrm{ha} / \mathrm{yr}$ depending upon the ash exportation scenario (Table 2c).

Si fluxes involved in the steady state $\mathrm{Si}$ cycle at Lamto are schematized Fig. 2, assuming 0\%, 50\% and 90\% ash exportation scenarios (Fig. 2(a), (b), and (c)).

\subsection{Impact of plant Si cycling on LSi release and DSi output}

The simplified steady-state $\mathrm{Si}$ cycle established for the $L$. simplex savanna/ferruginous soil at Lamto highlights that, assuming no ash exportation (Fig. 2(a)), to compensate for the BSi storage in soil (24 kg/ha/yr), $19 \%$ of DSi absorbed by plants ( $127 \mathrm{~kg} / \mathrm{ha} / \mathrm{yr}$ ) needs to be derived from $73 \%$ of $\mathrm{LSi}$ release (33 kg/ha/yr). In this first case, LSi release is approximately three times the DSi output $(9 \mathrm{~kg} / \mathrm{ha} / \mathrm{yr})$. If $50 \%$ of ash-BSi is exported (36 kg/ha/y) (Fig. 2(b)), BSi storage decreases to $17 \mathrm{~kg} / \mathrm{ha} / \mathrm{yr}$ and LSi release must increase by $53 \mathrm{~kg} / \mathrm{ha} / \mathrm{yr}$ in order to satisfy the annual plant uptake. The value represents $86 \%$ of the LSi release and $42 \%$ of the plant uptake. In this second case, the LSi release $(62 \mathrm{~kg} / \mathrm{ha} / \mathrm{yr})$ reaches approximately six times the DSi output $(9 \mathrm{~kg} / \mathrm{ha} / \mathrm{yr})$. If $90 \%$ of ash-BSi is exported $(65 \mathrm{~kg} / \mathrm{ha} / \mathrm{yr})$, the BSi storage decreases further to $12 \mathrm{~kg} / \mathrm{ha} / \mathrm{yr}$ and the LSi release must increase by $77 \mathrm{~kg} / \mathrm{ha} / \mathrm{yr}$. The value represents $90 \%$ of LSi release and $60 \%$ of plant uptake. In this third case, the LSi release $(85 \mathrm{~kg} / \mathrm{ha} / \mathrm{yr})$ is approximately eight times the DSi output $(9 \mathrm{~kg} / \mathrm{ha} / \mathrm{yr})$. Therefore, plant Si cycling involved in the present savanna/ferruginous soil ecosystem increases by three to eight times the net LSi release, depending upon the significance of ash exportation after the occurrence of annual fires, without any impact on DSi output.

\subsection{Comparison between savanna/ferruginous soil and rainforest/ ferrallitic soil Si cycles}

At Lamto, the savanna develops under MAP and MAT conditions that are close to those experienced by the southern rainforest domain. For instance, in the Mayombe rainforest (Dimonika, $4^{\circ} \mathrm{S}, 12^{\circ} 30 \mathrm{E}$, Democratic Republic of Congo), for which a schematic steady-state $\mathrm{Si}$ cycle was previously estimated (Fig. 2(c)), MAP and a MAT are, respectively, $1500 \mathrm{~mm}$ and $25.5^{\circ} \mathrm{C}$ (Alexandre et al., 1997). The rainforest, preserved from fires, grows on a ferrallitic soil, slightly less drained and with more SOC ( 0.5 to $1.1 \%$ of dry weight), secondary silicates (kaolinite: 10 to $25 \%$ of dry weight), and iron oxides (goethite: 6 to $27 \%$ of dry weight) than Lamto ferruginous soil. The parent-rocks are schists and quartzite, instead of the granite at Lamto. Therefore, vegetation, fire occurrence or not, soil SOC concentrations, and soil contents in clays and Fe oxides differentiate the two ecosystems. Comparison between the two steady-state Si cycles (Table 2c, Fig. 2) provides evidence of the following differences: (1) the DSi plant uptake is twice higher in the savanna than in the rainforest ecosystem (127 vs $67 \mathrm{~kg} / \mathrm{ha} / \mathrm{yr}$ ). (2) The BSi inputs are similar when $90 \%$ of ash exportation is assumed in the savanna, otherwise (when 50 or $0 \%$ of ash exportation is assumed) the BSi input is significantly higher in the savanna than in the rainforest (from 91 to 127 vs $67 \mathrm{~kg} / \mathrm{ha} / \mathrm{yr}$ ). (3) The BSi pools are similar (27 t/ha/ $\mathrm{yr}$ ), whereas the stable part is slightly higher in the savanna (12 vs $7 \mathrm{t}$ /
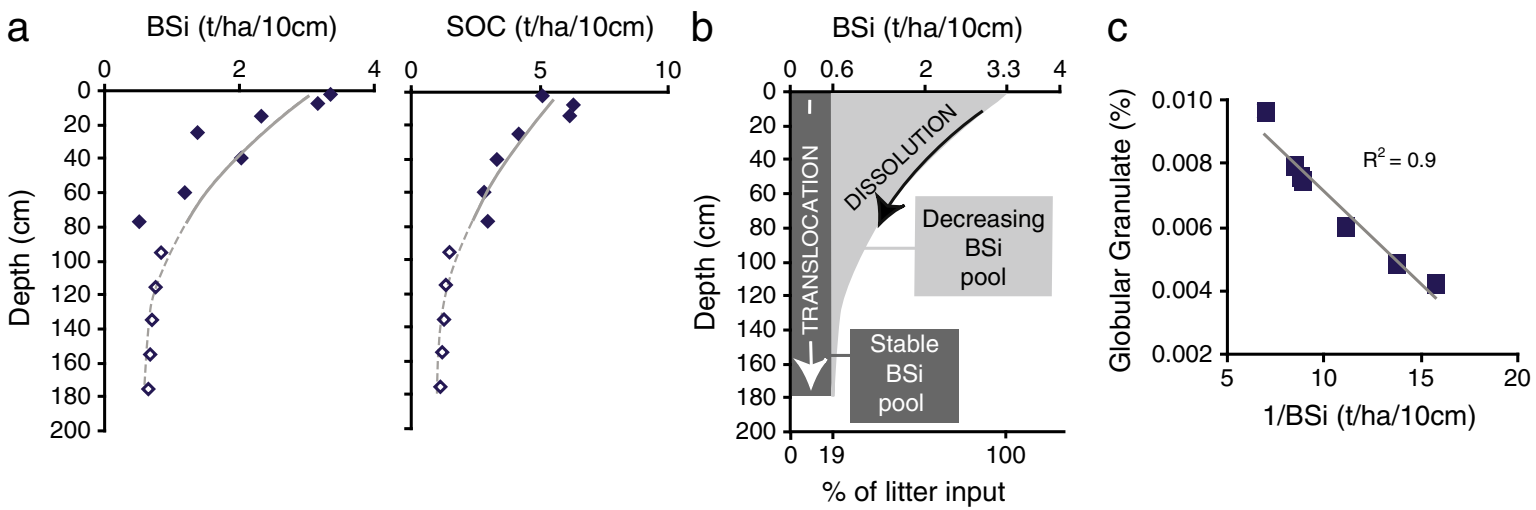

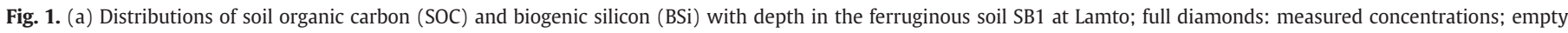

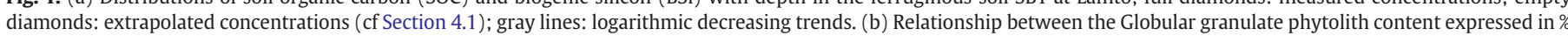
of counted phytoliths and 1/BSi content in the top portion (0-85 cm depth) of the soil. (c) Schematic bi-compartmental distribution of BSi in the soil. 
a

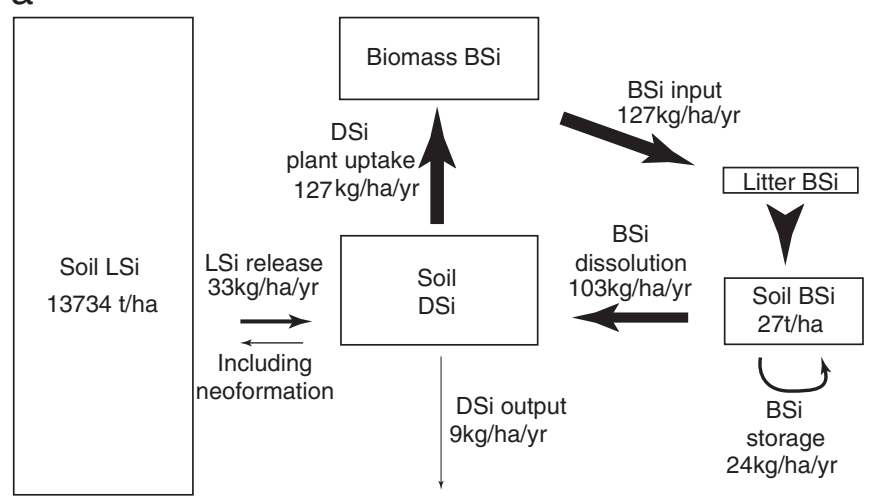

b

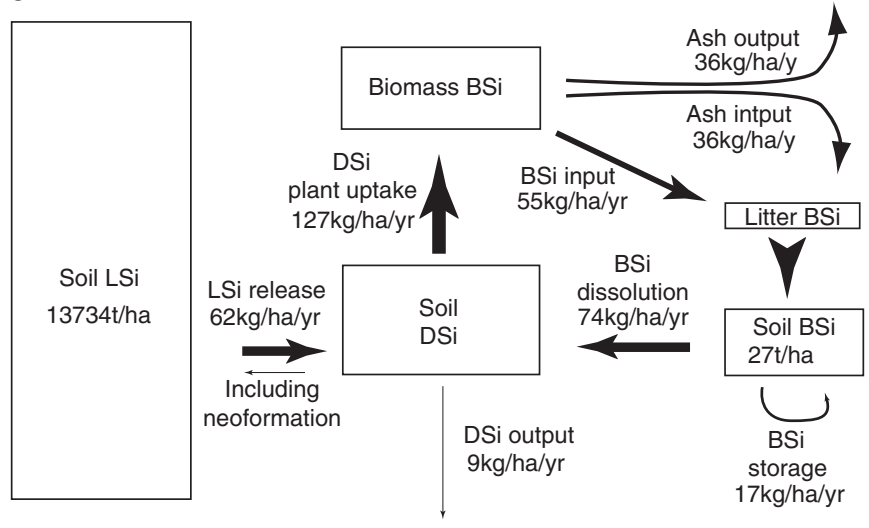

C

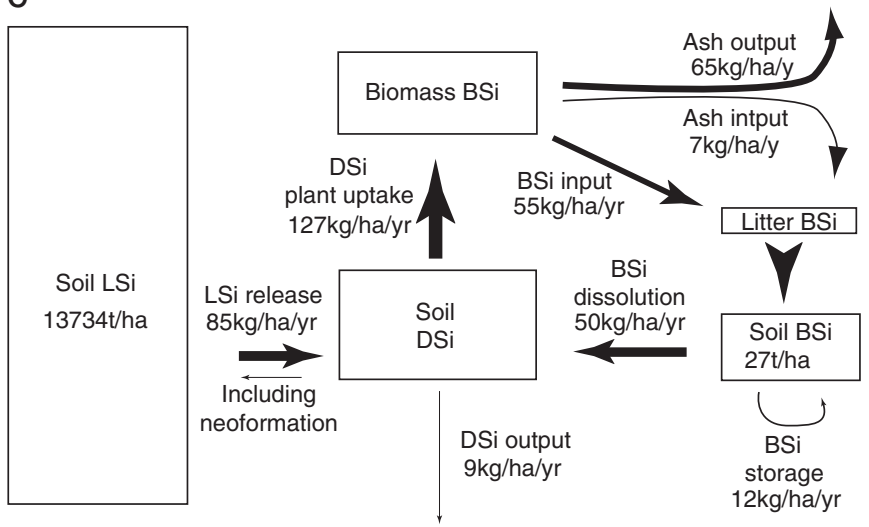

d

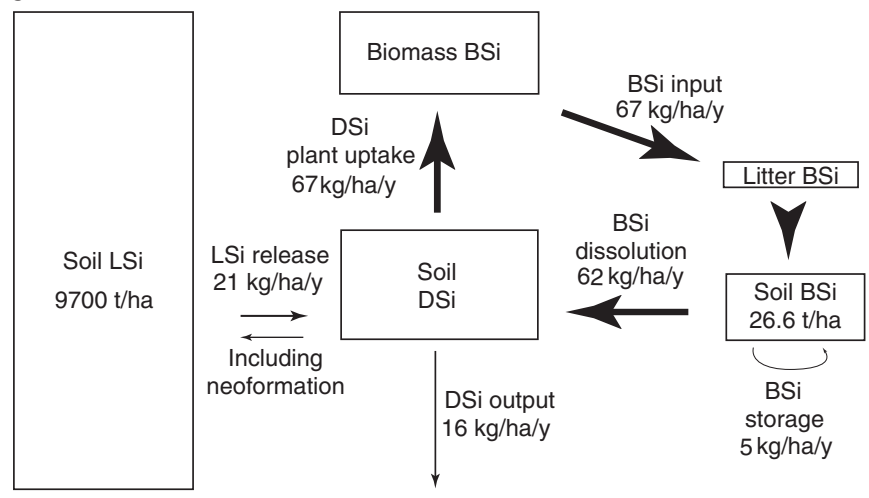

Fig. 2. Steady-state plant/soil Si cycles established for the savanna/ferruginous soil ecosystem assuming (a) $0 \%$, (b) $50 \%$ and (c) $90 \%$ of ash exportation. (d) Comparison with the Si cycle established for a rainforest/ferrallitic soil ecosystem, from Alexandre et al. (1997). ha/yr). (4) BSi storage is more than twice higher in savanna than in rainforest, regardless of the ash exportation scenario (24 to 12 vs $5 \mathrm{~kg} /$ ha/yr). (5) The LSi release required for satisfying the annual plant uptake (BSi storage plus BSi-ash exportation) is $5 \mathrm{~kg} / \mathrm{ha} / \mathrm{yr}$ in the rainforest compared to 24 to $77 \mathrm{~kg} / \mathrm{ha} / \mathrm{yr}$, depending on the ash exportation scenario, in the savanna. It represents $24 \%$ of the LSi release in the rainforest as compared to 73 to $90 \%$ in the savanna. Hence, plant Si cycling clearly shows a stronger impact on the net LSi release in the savanna than in the rainforest due to higher DSi uptake and BSi production by the high Si-accumulator grasses, and to a higher BSi storage in the ferruginous soil. As a result, the net LSi release is significantly higher in the savanna/ferruginous soil ecosystem than in the rainforest/ferrallitic soil ecosystem; impact of the plant Si cycling on LSi release is enhanced by ash exportation.

At the same time, an estimation of Si pools and fluxes allowed us to calculate the MRT of soil phytoliths. The MRT is indicative of the average amount of time that a particle spends in a particular system. Here, it is equal to the ratio of the BSi pool in soils vs the BSi input from vegetation (Table 2c). The MRT of the entire pool of phytoliths (total BSi) in both the savanna and the rainforest soils is similar if $90 \%$ of the ash exportation is assumed for the savanna (436 yr for the savanna vs $397 \mathrm{yr}$ for the forest, as calculated using Alexandre et al., 1997). The MRT of total BSi is slightly lower in the savanna when the 50 or $0 \%$ ash exportation scenarios are considered. In contrast, the MRT of the stable BSi pool is clearly higher in the rainforest ( $1400 \mathrm{yr}$ ) than in the savanna (486 to $993 \mathrm{yr}$ depending on the ash exportation scenario), suggesting that grass phytoliths dissolve faster in the ferruginous soil than tropical tree phytoliths (mainly represented by the Globular granulate type) in the ferrallitic soil. Clear relationships between the Globular granulate type and the inverse of the phytolith concentration obtained for both the savanna and the rainforest (Alexandre et al., 1997) support the hypothesis that for both contexts the stable BSi pools are significantly supplied by the Globular granulate type. Phytoliths are translocated in soils into claySOM aggregates (Bartoli, 1983). Micro-aggregates are considered to increase the physical protection of SOM from biodegradation (Balesdent et al., 2000) and may retard the dissolution of phytoliths protected by SOM. The stability of micro-aggregates increases with the concentration of SOM and clays that are higher in the forest ferrallitic soil than in the savanna ferruginous soil and may explain differences in the MRT of the stable BSi pool. Experimental studies have measured no difference in the dissolution rates of phytoliths, devoid of their organic matrix, from temperate grass and tree species, both being approximately two orders of magnitude higher than the dissolution rate of clays (Fraysse et al., 2006, 2009). However, the investigated types did not show strong differences in the shape and the specific surface area as should be the case between grass phytoliths and the Globular granulate type. Moreover, assuming that phytoliths are mainly translocated in soil aggregates, an investigation of phytolith capacity to aggregation, depending on the shape, the surface area, and the soil characteristics (e.g. SOM, clays, iron oxides contents) is needed to further assess the sensitivity of soil phytoliths to dissolution.

Finally, the present comparison shows evidence that the higher DSi uptake of the savanna overrides the lower MRT of grass phytoliths in the ferruginous soil and makes LSi release (through plant-induced chemical weathering) significantly higher than LSi release under the rainforest. The difference is enhanced when ash exportation occurs. On the contrary, the DSi output from the soil to the stream water, which is not controlled by plant Si cycling but more likely by the soil hydrological regimes (or meteoric weathering), is close to twice higher in the rainforest/ferrallitic soil ecosystem.

\subsection{Tracks for assessing the impact of grassland development on the terrestrial Si and C cycles}

The present study is based on rough estimates of Si fluxes, is limited to two plant/soil systems, and does not take into account the 
likely impact of climate changes on LSi release and DSi output. Other similar case studies are required to quantify with more precision, $\mathrm{Si}$ pools, net Si fluxes (including post-fire ash exportation), and respective significance of plant-induced and meteoric weathering on LSi release and DSi output at regional scale. However, the large differences in Si fluxes involved in the two plant/soil systems suggest that the expansion of savannas at the expense of forests mainly due to human impact as expected for the next hundred years, should significantly increase DSi uptake by plants, BSi storage in soils, BSi output with ash exportation, and, hence, LSi release and associated chemical weathering. The increasing drying of soils inherent to savanna expansion and to global warming (IPCC, 2007) may simultaneously decrease meteoric weathering and DSi concentrations. However this may not impact DSi uptake by grasses if, as it was recently demonstrated for the Banana Si-accumulator (Henriet et al., 2006), active DSi uptake (higher than the mass flow-driven flux) occurs when soil DSi concentration is low. Such an active DSi uptake may be genetically controlled, as in rice (Ma et al., 2006). In this case, expansion of savannas would enhance chemical weathering without increasing soil DSi available for neoformation and/or for feeding the Si output flow. On the contrary other elements placed in solution by chemical weathering, would either precipitate as secondary minerals or be leached out of the soil column. With deforestation, the amount of DSi exported from Phytolith-BSi stored in soils and litter will contribute to DSi fluxes toward stream waters only in weatheringlimited regime or during erosion phases, when subjected to transport and ulterior dissolution.

More generally our results are in agreement with previous case studies (Alexandre et al., 1997; Blecker et al., 2006) showing that in transport-limited regime (i.e. with no significant erosion) and when the plant/soil system is at equilibrium, DSi output to stream water during chemical denudation is controlled by the catchment surface area, the parent rocks, and the soil hydrological regime (e.g. Gaillardet et al., 1999a, 1999b; Millot et al., 2002; Dupré et al., 2003; Viers et al., 2009) rather than by plant Si cycling. This negates the common assumption that the amount of DSi leached out from soil profiles is linked to the magnitude of plant Si cycling (Derry et al., 2005; Conley et al., 2008; Cornelis et al., 2011) or to BSi concentration in soils (Laruelle et al., 2009).

With respect to general grassland expansion at the expense of forests, although a transitory period of erosion may lead to increasing export of DSi, long term grassland settlement and related high $\mathrm{Si}$ cycling should favor LSi release and weathering rather than DSi export, contrary to what was previously assumed from short term deforestation experiments (Conley et al., 2008). This is in agreement with close DSi flux recently measured from Belgian grasslands and forests downstreams (Struyf et al., 2010).

Forest primary production biomass and root biomass were believed to be two key ecosystem properties that enhance soil weathering rate (Pagani et al., 2009). Their decrease when atmospheric $\mathrm{CO}_{2}$ declined was supposed to decrease plant-induced weathering of silicates and limit $\mathrm{CO}_{2}$ drawdown (Pagani et al., 2009). The present case study however suggests that under widespread grassland development, increasing plant Si cycling, consequent increasing soil LSi weathering and associated increasing atmospheric $\mathrm{CO}_{2}$ consumption should be accounted, in geochemical carbon cycle models (e.g. Berner and Kothavala, 2001), for one of the plant-induced weathering mechanisms.

\section{Conclusions}

Identification and quantification of plant and soil phytoliths in the savanna/ferruginous soil ecosystem at Lamto indicated that the soil BSi pool was made of grass phytoliths with a few tree phytoliths, in equilibrium with the current BSi input by the savanna. In the soil column, mixing between a young decreasing BSi pool with a few Globular granulates produced by trees and an old stable BSi pool with a larger amount of Globular granulate was attested by the mixing line equation. The BSi pool with low turnover, is assimilated as a BSi output from the savanna/ferruginous soil steady-state Si cycle. In addition to soil BSi storage, BSi exportation may occur after annual fires if ashes are exported. Both of the BSi outputs decrease as much as the BSi dissolution. In order to uptake constant DSi flux, plants must increase (by an equal amount) soil LSi release and associated chemical weathering. Such a process has already been demonstrated for a rainforest/ferrallitic soil system that was established under climate conditions similar to the savanna site (Alexandre et al., 1997). The comparison between both $\mathrm{Si}$ cycles maximizes the differences in plant/soil systems and minimizes differences in climate. The comparison revealed that BSi storage is higher in the savanna soil than in the rainforest soil, mainly due to BSi production that is twice as high in the savanna. The resulting LSi release that is enhanced by plant Si cycling is more than 1.5 higher in the savanna than in the rainforest (from 33 to $85 \mathrm{~kg} / \mathrm{ha} / \mathrm{yr}$ in the savanna $v s 21 \mathrm{~kg} / \mathrm{ha} / \mathrm{yr}$ in the rainforest). The expected next hundreds years of expansion of savannas at the expense of forests should significantly increase DSi uptake by plants, BSi storage in soils, BSi output with ash exportation, and, hence, LSi release and associated chemical weathering, but should have no direct impact on DSi output from soils to stream waters.

Other similar case studies, are required to quantify with more precision, differences in Si pools and fluxes among plant/soil systems, and respective significance of plant-induced and meteoric weathering on LSi release and DSi output at a regional scale. However some tracks for further assessing the role of plant Si cycling on chemical weathering, $\mathrm{Si}$ and C cycles were suggested: 1 ) estimates of BSi fluxes that are wrongly based on the assumption that the amount of DSi leached out from soils is linked to the magnitude of plant Si cycling and/or to BSi concentration in soils should be reappraised; 2) changes in the magnitude of plant $\mathrm{Si}$ cycling should be accounted, in geochemical carbon cycle models, for one of the plant-induced weathering mechanisms.

\section{Acknowledgment}

This work was conducted in the frame of M. Bouvet Master thesis (2000, CEREGE, UPCAM), with the support of the AOI CEREGE UMR CNRS 6635. Comments from three anonymous reviewers highly improved the revised manuscript.

\section{References}

Abbadie, L., 1984. Evolution saisonnière du stock d'azote dans la strate herbacée d'une savane soumise au feu en Côte d'Ivoire. Acta Oecol Oecol Plant 5 (19), 321-334.

Abbadie, L., Gignoux, J., Le Roux, X., Lepage, M. (Eds.), 2006. Lamto. Structure, Functioning, and Dynamics of a Savanna Ecosystem. Springer, New York.

Alexandre, A., Meunier, J.D., Colin, F., Koud, J.M., 1997. Plant impact on the biogeochemical cycle of silicon and related weathering processes. Geochim. Cosmochim. Acta 61, 677-682.

Alexandre, A., Meunier, J.D., Lézine, A.M., Vincens, A., Schwartz, D., 1998. Phytoliths: indicators of grassland dynamics during the Late Holocene in intertropical Africa. Palaeogeogr. Palaeoclimatol. Palaeoecol. 136, 213-229.

Alexandre, A., Meunier, J.D., Mariotti, A., Soubies, F., 1999. Late Holocene phytolith and carbonisotope record from a latosol at Salitre, South-Central Brazil. Quat. Res. 51, 187-194.

Balesdent, J., Chenu, C., Balabane, M., 2000. Relationship of soil organic matter dynamics to physical protection and tillage. Soil Tillage Res. 53, 215-220.

Bartoli, F., 1983. The biogeochemical cycle of silicon in two temperate forest ecosystems. Env. Biogeochem. Ecol. Bull 35, 469-476.

Berner, R.A., 1997. The rise of plants and their effect on weathering and atmospheric $\mathrm{CO}_{2}$. Science 276, 544-546.

Berner, R.A., Kothavala, Z., 2001. Geocarb III: a revised model of atmospheric $\mathrm{CO}_{2}$ over Phanerozoic time. Am. J. Sci. 301 (2), 182-204.

Blecker, S.W., McCulley, R.L., Chadwick, O.A., Kelly, E.F., 2006. Biologic cycling of silica across a grassland bioclimosequence. Global Biogeochem. Cycles 20. doi:10.1029/ 2006GB002690.

Bond, W.J., Woodward, F.I., Midgley, G.F., 2005. The global distribution of ecosystems in a world without fire. New Phytol. 165 (2), 525-537.

Bozarth, S.R., 1992. Classification of opal phytoliths formed in selected dicotyledons native to the great plains. In: Rapp, Mulholand (Eds.), Phytolith Systematic. Plenum Press, New York. 350 p. 
Bremond, L., Alexandre, A., Hely, C., Guiot, J., 2005a. A phytolith index as a proxy of tree cover density in tropical areas: calibration with Leaf Area Index along a forestsavanna transect in southeastern Cameroon. Global Planet. Change 45, 277-293.

Bremond, L., Alexandre, A., Peyron, O., Guiot, J., 2005b. Grass water stress estimated from phytoliths in West Africa. J. Biogeogr. 32, 311-327.

Cary, L., Alexandre, A., Meunier, J.D., Boeglin, J.L., Braun, J.J., 2005. Contribution of phytoliths to the suspended load of biogenic silica in the Nyong basin rivers (Cameroon). Biogeochem 74, 101-114.

Conley, D.J., 2002. Terrestrial ecosystems and the global biogeochemical silica cycle. Global Biogeochem. Cycles 16 (4) 68-1.

Conley, D.J., Likens, G.E., Buso, D.C., Saccone, L., Bailey, S.W., Johnson, C.E., 2008 Deforestation causes increased dissolved silicate losses in the Hubbard Brook Experimental Forest. Global Change Biol. 14 (11), 2548-2554.

Cornelis, J.T., Delvaux, B., Georg, R.B., Lucas, Y., Ranger, J., Opfergelt, S., 2011. Tracing the origin of dissolved silicon transferred from various soil-plant systems towards rivers: a review. Biogeosciences 8 (1), 89-112.

Delire, C., Ngomanda, A., Jolly, D., 2008. Possible impacts of 21st century climate on vegetation in Central-West Africa. Global Planet. Change 64 (1-2), 3-15. doi:10.1016/j.glopacha.2008.01.008.

Derry, L.A., Kurtz, A.C., Ziegler, K., Chadwick, O.A., 2005. Biological control of terrestrial silica cycling and export fluxes to watersheds. Nature 433, 728-731.

Dessert, C., Dupré, B., Gaillardet, J., Francoois, L.M., Allègre, C.J., 2003. Basalt weathering laws and the impact of basalt weathering on the global carbon cycle. Chem. Geol. 202, 257-273.

Ding, T., Wan, D., Wang, C., Zhang, F., 2004. Silicon isotope compositions of dissolved silicon and suspended matter in the Yangtze River, China. Geochim. Cosmochim. Acta 68 (2), 205-216.

Dupré, B., Dessert, C., Oliva, P., Goddéris, Y., Viers, J., François, L., Millot, R., Gaillardet, J., 2003. Rivers, chemical weathering and Earth's climate. C. R. Geosci. 335, 1141-1160.

Favier, C., Chave, J., Fabing, A., Schwartz, D., Dubois, M.A., 2004. Modelling forestsavanna mosaic dynamics in man-influenced environments: effects of fire, climate and soil heterogeneity. Ecol. Modell. 171, 85-102.

Fraysse, F., Pokrovsky, O.L., Schott, J., Meunier, J.D., 2006. Surface properties, solubility and dissolution kinetics of phytoliths from bamboos of Reunion Island. Geochim. Cosmochim. Acta 70, 1939-1951.

Fraysse, F., Pokrovsky, O.S., Schott, J., Meunier, J.D., 2009. Surface chemistry and reactivity of plant phytoliths in aqueous solutions. Chem. Geol. 258, 197-206.

Gaillardet, J., Dupré, B., Louvat, P., Allègre, C.J., 1999a. Global silicate weathering and CO consumption rates deduced from the chemistry of large rivers. Chem. Geol. 159, $3-30$.

Gaillardet, J., Dupré, B., Louvat, P., Allègre, C.J., 1999b. Global silicate weathering and $\mathrm{CO}_{2}$ consumption rates deduced from the chemistry of the large rivers. Chem. Geol. 159, 3-30.

Geis, J.W., 1973. Biogenic silica in selected species of deciduous angiosperms. Soil Sci. $116(2), 113-119$

Harrison, K.G., 2000. Role of increased marine silica input on paleo-pCO $\mathrm{CO}_{2}$ levels. Paleoceanog 1015 (3), 292-298.

Henriet, C., Draye, X., Oppitz, I., Swennen, R., Delvaux, B., 2006. Effects, distribution and uptake of silicon in banana (Musa spp.) under controlled conditions. Plant Soil, 287, pp. 359-374.

Hinsinger, P., Barros, O.N.F., Benedetti, M.F., Noack, Y., Callot, G., 2001. Plant-induced weathering of a basaltic rock: experimental evidence. Geochim. Cosmochim. Acta $65,137-152$.

Hughes, H.J., Sondag, F., Cocquyt, C., Laraque, A., Pandi, A., André, L., Cardinal, D., 2011. Effect of seasonal biogenic silica variations on dissolved silicon fluxes and isotopic signatures in the Congo River. Limnol. Oceanogr. 56 (2), 551-561.

IPCC, 2007. Contribution of Working Groups I, II and III to the Fourth Assessment Report of the Intergovernmental Panel on Climate Change. In: Core Writing Team, Pachauri, R.K., Reisinger, A. (Eds.), IPCC, Geneva, Switzerland, p. 104

Jobbágy, E.G., Jackson, R.B., 2000. The vertical distribution of soil organic carbon and its relation to climate and vegetation. Ecol. Appl. 10, 423-436.

Kelly, E.F., 1990. Methods for extracting opal phytoliths from soil and plant material. Document of the Department of Agronomy, Colorado State University.

Kelly, E., Chadwick, O.A., Hilinsk, T.E., 1998. The effect of plants on mineral weathering. Biogeochem 42, 21-53.

Laruelle, G.G., Roubeix, V., Sferratore, A., Brodherr, B., Ciuffa, D., Conley, D.J., Dürr, H.H. Garnier, J., Lancelot, C., Le Thi Phuong, Q., Meunier, J.-D., Meybeck, M. Michalopoulos, P., Moriceau, B., N’1 Longphuirt, S., Loucaides, S., Papush, L., Presti, M., Ragueneau, O., Regnier, P.A.G., Saccone, L., Slomp, C.P., Spiteri, C., Van Cappellen, P., 2009. Anthropogenic perturbations of the silicon cycle at the global scale: key role of the land-ocean transition. Global Biogeochem. Cycles 23, GB4031. doi:10.1029/2008GB003267.

Le Roux, X., 1995. Etude et modélisation des échanges d'eau et d'énergie sol-végétationatmosphère dans une savane humide (Lamto, Côte d'Ivoire). $\mathrm{PhD}$ thesis. Université Pierre et Marie Curie, Paris.

Lucas, Y., Luizao, F.J., Rouiller, J., Nahon, D., 1993. The relation between the biological activity of the rain forest and the mineral composition of the soils. Science 260 521-523.
Ma, J.F., Tamai, K., Yamaji, N., Mitani, N., Konishi, S., Katsuhara, M., Ishiguro, M., Murata, Y., Yano, M., 2006. A silicon transporter in rice. Nature 440, 688-691.

Madella, M., Alexandre, A., Ball, T., 2005. International Code for Phytolith Nomenclature 1.0 (ICPN 1.0). An. Bot. 96, 253-260.

Martin, A., Mariotti, A., Balesdent, J., Lavelle, P., Vuattoux, R., 1990. Estimate of organic matter turnover rate in a savanna soil by ${ }^{13} \mathrm{C}$ natural abundance measurements. Soil. Biol. Biochem. 22, 517-523.

Menaut, J.C., Cesar, J., 1979. Structure and primary productivity of Lamto savannas. Ivory Coast. Ecol. 60, 1197-1210.

Meunier, J.D., Colin, F., Alarcon, C., 1999. Biogenic silica storage in soils. Geology 27 (9), 835-838.

Millot, R., Gaillardet, J., Dupré, B., Allègre, C.J., 2002. The global control of silicate weathering rates and the coupling with physical erosion: new insights from rivers of the Canadian Shield. Earth Planet. Sci. Lett. 196, 83-98.

Mistry, J., 2000. World savanna. Ecology and Human Use. Prentice Hall. 300 p.

Moulton, K.L., Berner, R.A., 1998. Quantification of the effect of plants on weathering: studies in Iceland. Geology 26 (10), 895-898.

Moulton, K.L., West, J., Berner, R.A., 2000. Solute flux and mineral mass balance approaches to the quantification of plant effects on silicate weathering. Am. J. Sci. 300, 539-570.

Nacro, H.B., Benest, D., Abbadie, L., 1996. Distribution of microbial activities and organic matter according to particle size in a humid savanna soil (Lamto, Côte d'Ivoire). Soil Biol. Biochem. 28 (12), 1687-1697.

Opfergelt, S., Cardinal, D., André, L., Delvigne, C., Bremond, L., Delvaux, B., 2010. Variations of $\delta^{30} \mathrm{Si}$ and $\mathrm{Ge} / \mathrm{Si}$ with weathering and biogenic input in tropical basaltic ash soils under monoculture. Geochim. Cosmochim. Acta 74, 225-240.

Pagani, M., Caldeira, K., Berner, R., Beerling, D., 2009. The role of terrestrial plants in limiting $\mathrm{CO}_{2}$ decline for 24 million years. Nature $460,85-88$.

Piperno, D.R., 2006. Phytoliths: a Comprehensive Guide for Archaeologists and Paleoecologists. Altamira Press, Lanham. 238 pp.

Runge, F., 1996. Opal Phytolithe in Pflanzen aus dem humiden und semi-ariden Osten Afrikas und ihre Bedeutung für die Klima-und Vegetationgeschichte. Bot. Jahrb. Syst. Pflanzengesch. Pflanzengeogr. 118, 303-363.

Runge, F., 1999. The opal phytolith inventory of soils in central Africa-quantities, shapes, classification, and spectra. Rev. Palaeobot. Palynol. 107, 23-53.

Sala, O.E., Chapin, F.S., Armesto, J.J., Berlow, E., Bloomfield, J., Dirzo, R., Huber-Sanwald, E., Huenneke, L.F., Jackson, R.B., Kinzig, A., Leemans, R., Lodge, D.M., Mooney, H.A., Oesterheld, M., Poff, N.L., Sykes, M.T., Walker, B.H., Walker, M., Wall, D.H., 2000. Biodiversity - Global biodiversity scenarios for the year 2100. Science 287 (5459), 1770-1774.

Sankaran, M., Hanan, N.P., Scholes, R.J., Ratnam, J., Augustine, D.J., Cade, B.S., Gignoux, J., Higgins, S.I., Le Roux, X., Ludwig, F., Ardo, J., Banyikwa, F., Bronn, A., Bucini, G., Caylor, K.K., Coughenour, M.B., Diouf, A., Ekaya, W., Feral, C.J., February, E.C., Frost, P.G.H., Hiernaux, P., Hrabar, H., Metzger, K.L., Prins, H.H.T., Ringrose, S., Sea, W., Tews, J., Worden, J., Zambatis, N., 2005. Determinants of woody cover in African savannas. Nature 438 (7069), 846-849.

Sommer, M., Kaczorek, D., Kuzyakov, Y., Breuer, J., 2006. Silicon pools and fluxes in soils and landscapes-a review. J. Plant Nutr. Soil Sci. 169, 310-329.

Street-Perrott, F.A., Barker, P.A., 2008. Biogenic silica: a neglected component of the coupled global continental biogeochemical cycles of carbon and silicon. Earth Surf. Processes Landforms 33, 1436-1457.

Struyf, E., Dausse, A., Van Damme, S., Bal, K., Gribsholt, B., Boschker, H.T.S., Middelburg, J.J., 2006. Tidal marshes and biogenic silica recycling at the land-sea interface. Limnol. Oceanogr. 51 (2), 838-846.

Struyf, E., Smis, A., Van Damme, S., Garnier, J., Govers, G., Van Wesemael, B., Conley, D.J., Batelaan, O., Frot, E., Clymans, W., Vandevenne, F., Lancelot, C., Goos, P., Meire, P., 2010. Historical land use change has lowered terrestrial silica mobilization. Nat. Commun. 1, 129. doi:10.1038/ncomms1128.

Taylor, L.L., Leake, J.R., Quirk, J., Hardy, K., Banwart, S.A., Beerling, D.J., 2009. Biological weathering and the long-term carbon cycle: integrating mycorrhizal evolution and function into the current paradigm. Geobiology 7, 171-191. doi:10.1111/j.14724669.2009.00194.

Tréguer, P., Pondaven, P., 2000. Silica control of carbon dioxide. Nature 406, 358-359.

Viers, J., Dupré, B., Gaillardet, J., 2009. Chemical composition of suspended sediments in World Rivers: new insights from a new database. Sci. Total. Environ. 407, 853-868.

Villecourt, P., Roose, E., 1978. Charge en Azote et en elements minéraux majeurs des eaux de pluie, de pluviolessivage et de drainange dans la savane de Lamto (Côte d'Ivoire). Rev. Ecol. Biol. Sol 15, 1-20.

Webb, E.A., Longstaffe, F.J., 2000. The oxygen isotopic compositions of silica phytoliths and plant water in grasses: implications for the study of paleoclimate. Geochim. Cosmochim. Acta 64, 767-780.

Webb, E.A., Longstaffe, F.J., 2002. Climatic influences on the oxygen isotopic composition of biogenic silica in prairie grass. Geochim. Cosmochim. Acta 66 (11), 1891-1904.

White, F., 1983. The Vegetation Map of Africa. UNESCO, Paris. 356 pp.

Ziegler, K., Chadwick, O.A., White, A.F., Brzezinski, M.A., 2005. $\delta^{30} \mathrm{Si}$ systematics in a granitic saprolite, Puerto Rico. Geology 33 (10), 817-820. 